Journal of Environmental Sciences (JES)

Faculty of Graduate Studies and Environmental Research, Ain Shams University

Abd Elwahab, Shaimaa A., et al.

\title{
NEPHRO-PROTECTIVE EFFECTS OF GRAPE AND GUAVA SEEDS EXTRACTS ON GENTAMICIN
}

\section{INDUCED NEPHROTOXICITY IN RATS}

\author{
Shaimaa A.Abd Elwahab ${ }^{(1)}$; Maha M. Mohamed ${ }^{(2)}$; \\ Awatif M.Abdel-maksoud ${ }^{(3)}$ and Eman M.Sadek ${ }^{(4)}$
}

1) The Blood laboratory department, National Nutrition Institute, Cairo, Egypt 2) Home Economic Department, Women's College, Ain Shams University 3) Nutritional Needs and Growth Department, National Nutrition Institute, Cairo, Egypt. 4) Histology Department, Faculty of Medicine, Cairo University, Cairo, Egypt.

\begin{abstract}
This study was conducted to investigate the nephro- protective effects of grape and / or guava seeds extracts on gentamicin induced nephrotoxicity in rats. Fifty seven adult male albino rats were divided into 8 groups. Group 1 (control group) was injected intraperitonealy with saline solution; groups (2, 3 and 4 were administrated a daily oral dose of grape $(40 \mathrm{mg} / \mathrm{kg} / \mathrm{d}$ p.o), guava seeds extracts $(300 \mathrm{mg} / \mathrm{kg} / \mathrm{d}$ p.o) or mixture of both, respectively; group 5 was intoxicated with gentamicin $(100 \mathrm{mg} / \mathrm{kg} /$ day i.p); groups $(6,7$ and 8) received oral dose of grape and / or guava seeds extracts along with intraperitonealy injection of gentamicin for 10 days. At the end of the experimental period (10 days) rats were scarified and serum was collected for serum creatinine, urea, uric acid and total protein. Parameters of oxidative stress were determined including reduced glutathione (GSH), malondialdehyde, and activity of erythrocyte superoxide dismutase $(\mathrm{Cu}, \mathrm{Zn}$ SOD). The results of the present study revealed that treatment of normal rats with grape and / or guava seeds extracts did not show any adverse physiological effects. Gentamicin injection resulted in significant elevation in serum levels of creatinine and blood urea nitrogen.


While, serum total protein was not significantly changed. Administration of gentamicin caused a significant decrement in blood GSH level, erythrocyte $\mathrm{Cu}, \mathrm{Zn}$-SOD activity, renal level of reduced glutathione and elevation in level of renal MDA. Treatment with grape and /or guava seeds extracts produced protective effects and attenuated these biochemical changes. The histological examination confirmed the protective effects of grape and /or guava seeds extracts. In conclusion, this study suggested that treatment with grape seeds and / or guava seeds extracts protect against gentamicin induced nephrotoxicity.

Keywords: Gentamicin, nephrotoxicity, antioxidants, grape seeds extract, guava seeds extract.

\section{INTRODUCTION}

Gentamicin (GM) is an efficacious aminoglycoside antibiotic widely used to treat life-threatening Gram-negative bacteria infections (Edeogu et al., 2020). Despite their extensive application and positive effects, drugrelated toxicity is considered as the main obstacle for aminoglycosides. Aminoglycosides induce nephrotoxicity through the endocytosis and accumulation of the antibiotics in the epithelial cells of proximal tubule (Mahi-Birjand et al., 2020). The drug may accumulate in epithelial tubular cells causing arrange of effects starting with loss of the brush border in epithelial cell and ending in overt tubular necrosis, activation of apoptosis and massive proteolysis. GM also causes cells death by generation of free radicals, phospholipidosis, extracellular calcium-sensing receptor stimulation, reduced renal blood flow and inflammation (Shi et al., 2003 and Ali et al., 2011). Moreover, a reduced glomerular filtration is the 
Journal of Environmental Sciences (JES)

Faculty of Graduate Studies and Environmental Research, Ain Shams University

Abd Elwahab, Shaimaa A., et al.

symptoms of the disease. Reduced filtration is not solely the result of tubular malfunction and tubular obstruction, but it may result from the renal vasoconstriction; tubuloglomerular feedback activation and mesangial contraction (Lopez-Novoa et al., 2011).

Nephrotoxicity is the major side effects of aminoglycoside antibiotics such as gentamicin (Hajihashemi et al., 2018). Several attempts to ameliorate GM nephrotoxicity have been made, using variety of agents including phospholipids, fish oil and free radical scavengers such as selenium, vitamin E and dimethyl sulfoxide. None of these agents were completely successful in ameliorating or reversing GM nephrotoxicity (Tang et al., 2012).

The screening of plants and their different parts for health -promoting activities has been a prim priority due to their natural quality and the fact that they produce the least side effects after supplementation.

Grapes are one of the most highly consumed fruits across the world. In ancient Europe the leaves and the sap of grape plants has been used in traditional treatment for ages (Gupta et al., 2020). Grape seed extract (GSE) is a polyphenolic mixture exhibiting antioxidant and anti-inflammatory properties (Turki et al., 2016). GSE protects the kidney (Charradi et al., 2013) against high fat diet (HFD)-induced obesity and lipotoxicity in rat. Furthermore high dosage GSE was even shown to improve renal injury in type 2 diabetic rats through its anti-oxidant and anti-inflammatory properties (Bao et al., 2015). Grape seed extract (GSE) contains several flavonoids 
such as proanthocyanidin oligomers. It has been demonstrated that the antioxidant properties of proanthocyanidin oligomers is nearly 50 times greater than that of vitamin $\mathrm{C}$ and $\mathrm{E}$ (Zhou et al., 2011). Moreover, such flavonoids possess several other effects such as vasodilatory, antiinflammatory, endothelial nitric oxide synthase (NOS) activating and inducible NOS inhibiting effects. In addition, it has been found that using proanthocyanidin decreases renal damage following gentamicin and cisplatin administration (Safa et al., 2010).

Previous studies revealed that guava has been identified and used as a functional food (Joseph and Priya, 2011). The different parts (leaves, pulp, bark and seeds) of guava have been proved to be antibacterial (Kenneth et al., 2017), antiproliferative (sulain et al 2012), antispasmodic and immunostimulant (Laily et al., 2015). Guava have broad spectrum of active ingredients such as polysaccharides, vitamins, minerals, polyphenols, antioxidants ,carotenoids, lutein, zeaxanthine, tannins, saponins, essential oils, pectin, dietary fiber and fatty acids (Joseph and Priya, 2011). All these compositional attributes make guava suitable for pharmaceutical applications. It was found that the aqueous and ethanol extract of guava fruit could protect the kidney of diabetic mice against diabetic progression via its anti-oxidative, anti - inflammatory, anti-glycative effect (Lin and Yin, 2012). 
Journal of Environmental Sciences (JES)

Faculty of Graduate Studies and Environmental Research, Ain Shams University

Abd Elwahab, Shaimaa A., et al.

The present study aimed to investigate the nephron-protective effects of grape and / or guava seeds extract on gentamicin induced nephrotoxicity in rats

\section{MATERIALS AND METHODS}

Chemicals: Gentamicin sulphate: was purchased from Chemical Industries Development Company (CID), Giza, Egypt, as a pure powder. It was dissolved freshly in saline prior to each treatment.

Animals: A total of 50 male Sprague- Dawley adult albino rats were used in this study, their body weight ranged from 200-250 gm. The animals were housed in metallic cages under healthy environmental condition. Rats were fed with normal pellet diet and were free access to water.

Preparation of extracts: After extracting the grape juice or guava juice the obtained seeds were dried in shade, milled, and turned into powder. Then $500 \mathrm{ml}$ of $70 \%$ ethanol was added for every $500 \mathrm{~g}$ of the powder and mixed in rotary at room temperature for one day. The obtained mixture was again rotated in $40^{\circ} \mathrm{C}$ incubators. With gradual reduction of temperature, the mixture turned into a thick black solution which was easily soluble in water (Enginar et al., 2007). Biological experiment: Rats were randomly assigned to 8 groups as follow: Group 1 (The negative control group): Rats were injected intrapritoneally (i.p) with saline $(0.9 \% \mathrm{Nacl})$, at the same volume as gentamicin $(\mathrm{GM})$ treated rats. 
Group 2: Rats received grape seed extract at dose of (40 mg/kg/day p.o) (Safa et al., 2010).

Group 3: Rats received guava seed extract at a dose of (300 mg/kg/day p.o) (Muruganandan et al., 2001)

Group 4: Rats received mixed dose of grape seeds extract $(40 \mathrm{mg} / \mathrm{kg} / \mathrm{day}$ p.o) and guava seed extract (300 mg/kg/d p.o).

Group 5 (Positive control group): Rats were injected with gentamicin at a dose of (100 mg/kg/day i.p) (Dhanarajan et al., 2006).

Group 6: Rats were injected with gentamicin (100 mg/ kg/day p.o) and received grape seed extract at a dose of (40 mg/kg/day p.o).

Group 7: Rats were injected with gentamicin (100 mg/ kg/day p.o) and received guava seed extract at a dose of $(300 \mathrm{mg} / \mathrm{kg} / \mathrm{d}$ p.o)

Group 8: Rats were injected with gentamicin (100 mg/ kg/day p.o) and received mixed dose of grape seed extract $(40 \mathrm{mg} / \mathrm{kg} / \mathrm{d}$ p.o) and Guava seed extract (300 mg/kg/day p.o).

Sample Collection and Biochemical Assays: At the end of treatment period 10 days, 24 hours after the last injection, the animals were scarified under diethyl ether anesthesia. Incitation were made into the abdomen and blood of each animal was collected from the portal vein in heparinized tube for plasma separation and dry centrifuge tube for serum, serum was separated by centrifugation at 3000 r.p.m for 15 minutes. Serum aliquots were frozen at -20 for subsequent determination of creatinine, urea, uric acid, total proteins by using photometric system auto analyzer( biotecnica 338

Vol.(50); Iss.(9); No.(4); Sep. 2021

ISSN $1110-0826$

Online ISSN 2636-3178 
Journal of Environmental Sciences (JES)

Faculty of Graduate Studies and Environmental Research, Ain Shams University

Abd Elwahab, Shaimaa A., et al.

instrument Via Licenza ,18 00155 Rome Italy). The heparinized blood samples were used for the determination of reduced glutathione $(\mathrm{GSH})$ according to Beutler et al (1963). The erythrocytes were washed twice with cold saline and kept for $\mathrm{Zn}, \mathrm{Cu}-\mathrm{SOD}$ estimation at $-20^{\circ} \mathrm{c}$ (Winterbourn et al., 1975). A portion of ( $0.5 \mathrm{~g})$ of the left kidney was homogenized with $1.2 \% \mathrm{KCL}$ solution to make a $10 \%$ renal homogenate. The homogenate was used for determination of both renal content of malondialdehyde (MDA) according to Uchiyama and Mihara (1978) and reduced glutathione GSH according to Beutler et al (1963).

Histological analysis: The right kidney was fixed in formalin solution, the specimens were embedded in paraffin and cut into multiple sections and stained with hematoxylin-eosin for light microscopic evaluation (Safa et al., 2010).

Statistical analysis: Statistical analysis were performed using computer program Statistical Packages for Social Science (IBM, 2012) and values were compared with each other using one-way analysis of variance (ANOVA) as all parameter is normally distributed and post hoc multiple comparison.

\section{RESULTS}

Normal rats groups: The treatment of normal rats with grape seeds extract, guava seeds extract or mixture of both had no significant effects on serum creatinine, blood urea nitrogen, serum total protein, blood GSH level, 
Journal of Environmental Sciences (JES)

Faculty of Graduate Studies and Environmental Research, Ain Shams University

Abd Elwahab, Shaimaa A., et al.

erythrocyte $\mathrm{Cu}, \mathrm{Zn}-\mathrm{SOD}$ activity and renal contents of reduced glutathione and malondialdehyde as compared with negative control. Serum uric acid was significantly reduced by $18.7 \%$ and $23.7 \%$ in groups 2 and 3 treated with grape seeds and guava seeds extracts respectively as compared with negative control (Table 1\&2).

Gentamicin treated rats: Injection of gentamicin caused significant elevation in serum creatinine and blood urea nitrogen reaching 10 and 8 folds, respectively as compared to negative control. On the other hand, neither serum uric acid nor total proteins were significantly affected by gentamicin injection (table 1). Data also indicated that treatment with the extracts of grape seeds and guava seeds or their combination attenuated gentamicin induced nephrotoxicity as evident from significant reduction in serum creatinine by $43.6 \%, 68 \%$ and $43 \%$ respectively, as compared with positive control. Moreover, Blood urea nitrogen BUN was significantly decreased by $45 \%$ in gentamicin injected rats received guava seed extract.

Meanwhile, the groups treated with grape seeds extract or mixed extracts exhibited non significant reduction in BUN as compared with positive control. Furthermore, serum uric acid was significantly reduced by $20.7 \%, 28.5 \%$ and $39.2 \%$ respectively in gentamicin injected rats received the extracts of grape seeds or guava seeds or their combination as compared with positive control. No considerable alterations were exhibited in serum total protein in gentamicin treated rats received grape seeds extract and / or guava seeds extract (table 1). 
Journal of Environmental Sciences (JES)

Faculty of Graduate Studies and Environmental Research, Ain Shams University

Abd Elwahab, Shaimaa A., et al.

Results presented in table (2) clarify that administration of gentamicin caused significant decrement in blood GSH level and erythrocyte $\mathrm{Cu}, \mathrm{Zn}$ SOD activity by $20 \%$ and $30 \%$, respectively, as compared with positive control. This reduction in blood GSH and erythrocyte $\mathrm{Cu}, \mathrm{Zn}-\mathrm{SOD}$ activity was significantly improved in the groups received grape seeds extract, guava seeds extract and their mixture as level of blood reduced GSH was significantly increased by $41.6 \%, 48.5 \%$ and $21.4 \%$, respectively. Meanwhile erythrocyte $\mathrm{Cu}, \mathrm{Zn}-\mathrm{SOD}$ activity was significantly increased by $31.3 \%$ and $40.2 \%$ in the groups treated with the extracts of grape seeds and guava seeds. On the other hand, the group received mixture of both extracts showed non significant increase as compared with positive control.

Table (2) also demonstrated that gentamicin injection caused impairment in renal antioxidant status as characterized by significant reduction in renal level of reduced glutathione by $33.7 \%$ as compared to negative control, this reduction in renal antioxidant status was accompanied by considerable elevation in renal lipid peroxidation as shown by significant higher level of renal MDA in gentamicin intoxicated animals as compared with negative control. The altered levels of renal GSH and MDA were restored with administration of grape seeds extract, guava seeds extract or their mixture.

The level of renal GSH was significantly increased by $40.7 \%, 29.1 \%$ and $27 \%$, respectively, where as the level renal MDA was significantly 
Journal of Environmental Sciences (JES)

Faculty of Graduate Studies and Environmental Research, Ain Shams University

Abd Elwahab, Shaimaa A., et al.

decreased by $38.5 \%, 40 \%$ and $41.7 \%$, respectively, as compared with gentamicin treated rats.

\section{HISTOLOGICAL RESULTS:}

Fig (1): Kidney of rats from group 1 showed normal glomeruli (black arrow), proximal convoluted tubules $\mathrm{P}$ and distal convoluted tubules $\mathrm{D}(\mathrm{H} \&$ E X400), Group 2, 3 and 4 demonstrated almost normal appearance of glomeruli and tubules with minimal hydropic degeneration in tubules (arrow). In group 5, there was hydropic degeneration in tubules (black arrow), acidophilic casts in tubules (green arrow), congestion of blood vessels (red arrow) and lymphocytic infiltration (blue) arrow (H \&X400). While, less damage in renal tubules was present in groups 6, 7 and 8 compared to group 5 . 
Journal of Environmental Sciences (JES)

Faculty of Graduate Studies and Environmental Research, Ain Shams University

Abd Elwahab, Shaimaa A., et al.

\begin{tabular}{|c|c|c|c|c|c|c|c|c|}
\hline \multirow[b]{2}{*}{ Parameters } & \multicolumn{4}{|c|}{ Normal rats } & \multicolumn{4}{|c|}{ Gentamicin treated rats } \\
\hline & $\begin{array}{l}\text { Negative } \\
\text { control } \\
(n=6)\end{array}$ & $\begin{array}{l}\text { Grape } \\
\text { seeds } \\
\text { extract } \\
(n=6)\end{array}$ & $\begin{array}{l}\text { Guava } \\
\text { seeds } \\
\text { extract } \\
(n=6)\end{array}$ & $\begin{array}{l}\text { Grape } \\
\text { seeds + } \\
\text { Guava } \\
\text { seeds } \\
(n=6)\end{array}$ & $\begin{array}{l}\text { Positive } \\
\text { Control } \\
(n=8)\end{array}$ & $\begin{array}{l}\text { Grape seeds } \\
\text { extract } \\
(n=6)\end{array}$ & $\begin{array}{l}\text { Guava } \\
\text { seeds } \\
\text { extract } \\
(n=6)\end{array}$ & $\begin{array}{l}\text { Grape } \\
\text { seeds }+ \\
\text { Guava } \\
\text { seeds } \\
(n=6)\end{array}$ \\
\hline $\begin{array}{l}\text { Serum creatinine } \\
(\mathrm{mg} / \mathrm{dl})\end{array}$ & $\begin{array}{l}\text { a } \\
0.70 \pm 0.02\end{array}$ & $\begin{array}{l}\text { a } \\
0.650 \pm 0.02\end{array}$ & $\begin{array}{l}\mathrm{a} \\
0.7 \pm 0.0\end{array}$ & $\begin{array}{l}\mathrm{a} \\
0.7 \pm 0.04\end{array}$ & $\begin{array}{l}\mathrm{d} \\
7.2 \pm 0.82\end{array}$ & $\begin{array}{l}c \\
4.06 \pm 0.26\end{array}$ & $\begin{array}{l}\mathrm{abc} \\
2.32 \pm 0.19\end{array}$ & $\begin{array}{l}\mathrm{cb} \\
4.1 \pm 0.81\end{array}$ \\
\hline $\begin{array}{l}\text { Blood urea } \\
\text { nitrogen }(\mathrm{BUN}) \\
(\mathrm{mg} / \mathrm{dl})\end{array}$ & $\begin{array}{l}\mathrm{a} \\
33.66 \pm 2.8\end{array}$ & $\begin{array}{l}\text { a } \\
38.5 \pm 1.19\end{array}$ & $\begin{array}{l}\mathrm{a} \\
42.5 \pm 2.72\end{array}$ & $\begin{array}{l}\text { a } \\
36.25 \pm 1.43\end{array}$ & $\begin{array}{l}\mathrm{c} \\
296.5 \pm 25.5\end{array}$ & $\begin{array}{l}\mathrm{c} \\
246.33 \pm 11.07\end{array}$ & $\begin{array}{l}\mathrm{b} \\
163.25 \pm 26.4\end{array}$ & $\begin{array}{l}b c \\
236.75 \pm 44.7\end{array}$ \\
\hline $\begin{array}{l}\text { Serum uric acid } \\
(\mathrm{mg} / \mathrm{dl}\end{array}$ & $\begin{array}{l}\text { e } \\
1.60 \pm 0.77\end{array}$ & $\begin{array}{l}\text { cd } \\
1.3 \pm 0.04\end{array}$ & $\begin{array}{l}\text { bcd } \\
1.22 \pm 0.06\end{array}$ & $\begin{array}{l}\text { de } \\
1.5 \pm 0.07\end{array}$ & $\begin{array}{l}\mathrm{de} \\
1.4 \pm .08\end{array}$ & $\begin{array}{l}\text { bc } \\
1.11 \pm 0.10\end{array}$ & $\begin{array}{l}\mathrm{ab} \\
1.0 \pm 0.04\end{array}$ & $\begin{array}{l}\mathrm{a} \\
0.85 \pm 0.06\end{array}$ \\
\hline $\begin{array}{l}\text { Serum total } \\
\text { protein } \\
(\mathrm{g} / \mathrm{dl})\end{array}$ & $\begin{array}{l}\text { a } \\
6.16 \pm 0.11\end{array}$ & $\begin{array}{l}a \\
6.62 \pm 0.11\end{array}$ & $\begin{array}{l}\mathrm{a} \\
6.62 \pm 0.19\end{array}$ & $\begin{array}{l}a \\
6.6 \pm 0.12\end{array}$ & $\begin{array}{l}\mathrm{a} \\
6.47 \pm 0.17\end{array}$ & $\begin{array}{l}\mathrm{b} \\
6.78 \pm 0.24\end{array}$ & $\begin{array}{l}\text { a } \\
6.47 \pm 0.08\end{array}$ & $\begin{array}{l}\mathrm{a} \\
6.35 \pm 0.06\end{array}$ \\
\hline
\end{tabular}

Table(1): Effects of grape and /or guava seeds extracts on kidney function tests in normal and gentamicin treated rat

The values represented the means \pm SEM.

The number of rats is given in the parentheses.

The different letters means that there is significant difference between groups at $(\mathrm{p}<0.05)$.

The same letters means that there is no significant difference between groups at $(\mathrm{p}>0.05)$. 
Journal of Environmental Sciences (JES)

Faculty of Graduate Studies and Environmental Research, Ain Shams University

Abd Elwahab, Shaimaa A., et al.

\begin{tabular}{|c|c|c|c|c|c|c|c|c|}
\hline \multirow[b]{2}{*}{ Parameters } & \multicolumn{4}{|c|}{ Normal rats } & \multicolumn{4}{|c|}{ Gentamicin treated rats } \\
\hline & $\begin{array}{l}\text { Negative } \\
\text { control } \\
(n=6)\end{array}$ & $\begin{array}{l}\text { Grape } \\
\text { seeds } \\
\text { extract } \\
(n=6)\end{array}$ & $\begin{array}{l}\text { Guava } \\
\text { seeds } \\
\text { extract } \\
(n=6)\end{array}$ & $\begin{array}{l}\text { Grape } \\
\text { seeds + } \\
\text { Guava } \\
\text { seeds } \\
(\mathrm{n}=6)\end{array}$ & $\begin{array}{l}\text { Positive } \\
\text { Control } \\
(\mathrm{n}=8)\end{array}$ & $\begin{array}{l}\text { Grape } \\
\text { seeds } \\
\text { extract } \\
(n=6)\end{array}$ & $\begin{array}{l}\text { Guava } \\
\text { seeds } \\
\text { extract } \\
(\mathrm{n}=6)\end{array}$ & $\begin{array}{l}\text { Grape } \\
\text { seeds + } \\
\text { Guava } \\
\text { seeds } \\
(\mathrm{n}=6)\end{array}$ \\
\hline $\begin{array}{c}\text { Blood GSH } \\
(\mathrm{mg} / \mathrm{dl})\end{array}$ & $\begin{array}{c}a c \\
43.5 \pm 0.99\end{array}$ & $\begin{array}{c}\text { ecd } \\
46.75 \pm 1.03\end{array}$ & $\begin{array}{c}\text { aecd } \\
46.0 \pm 1.08 \\
\end{array}$ & $\begin{array}{c}a \\
40.5 \pm 1.32 \\
\end{array}$ & $\begin{array}{c}b \\
34.8 \pm 0.71\end{array}$ & $\begin{array}{c}\mathrm{e} \\
49.33 \pm 3.39 \\
\end{array}$ & $\begin{array}{c}d \\
51.75 \pm 3.52\end{array}$ & $\begin{array}{c}\mathrm{ac} \\
42.25 \pm 1.03 \\
\end{array}$ \\
\hline $\begin{array}{c}\text { Renal GSH } \\
(\mathrm{mg} / \mathrm{g})\end{array}$ & $\begin{array}{c}b \\
48.16 \pm 1.77\end{array}$ & $\begin{array}{c}b \\
47.5 \pm 0.28\end{array}$ & $\begin{array}{c}b c \\
49 \pm 3.39\end{array}$ & $\begin{array}{c}b \\
47.5 \pm 2.1\end{array}$ & $\begin{array}{c}a \\
31.9 \pm 1.07\end{array}$ & $\begin{array}{c}c \\
53.83 \pm 2.62\end{array}$ & $\begin{array}{c}b \\
45 \pm 2.12\end{array}$ & $\begin{array}{c}b \\
44.25 \pm 0.94\end{array}$ \\
\hline $\begin{array}{c}\text { Renal MDA } \\
\text { (n mol/g) }\end{array}$ & $\begin{array}{c}a \\
41 \pm 0.68\end{array}$ & $\begin{array}{c}a \\
40.25 \pm 0.94\end{array}$ & $\begin{array}{c}a \\
39.25 \pm 0.85\end{array}$ & $\begin{array}{c}a \\
39.5 \pm 1.32\end{array}$ & $\begin{array}{c}b \\
55.8 \pm 1.10\end{array}$ & $\begin{array}{c}c \\
31.33 \pm 0.98\end{array}$ & $\begin{array}{c}c \\
33.25 \pm 0.85\end{array}$ & $\begin{array}{c}c \\
32.5 \pm 1.32\end{array}$ \\
\hline $\begin{array}{c}\text { Erythrocyte } \\
\mathrm{Cu}, \mathrm{Zn}-\mathrm{SOD} \\
(\mathrm{U} / \mathrm{ml}) \\
\end{array}$ & $\begin{array}{c}b \\
18.16 \pm 0.6\end{array}$ & $\begin{array}{c}b \\
17.5 \pm 2.17\end{array}$ & $\begin{array}{c}b \\
16.75 \pm 0.47\end{array}$ & $\begin{array}{c}a b \\
16.5 \pm 0.64\end{array}$ & $\begin{array}{c}a \\
12.7 \pm 0.5\end{array}$ & $\begin{array}{c}b \\
18.5 \pm 2.17\end{array}$ & $\begin{array}{c}b \\
21.25 \pm 2.85\end{array}$ & $\begin{array}{c}a b \\
16.5 \pm 1.75\end{array}$ \\
\hline
\end{tabular}

Table(2): Effects of grape and /or guava seeds extracts on blood and renal level of reduced glutathione (GSH), renal level of malondialdehyde (MDA) and erythrocyte superoxide dismutase activity $\mathrm{Cu}, \mathrm{Zn}-\mathrm{SOD}$ in normal rats and gentamicin treated rats

The values represent the mean \pm SEM.

The number of rats is given in the parentheses.

The different letters means that there is significant difference between groups at $(\mathrm{p}<0.05)$.

The same letters means that there is no significant difference between groups at $(\mathrm{p}>0.05)$. 
Journal of Environmental Sciences (JES)

Faculty of Graduate Studies and Environmental Research, Ain Shams University

Abd Elwahab, Shaimaa A., et al.
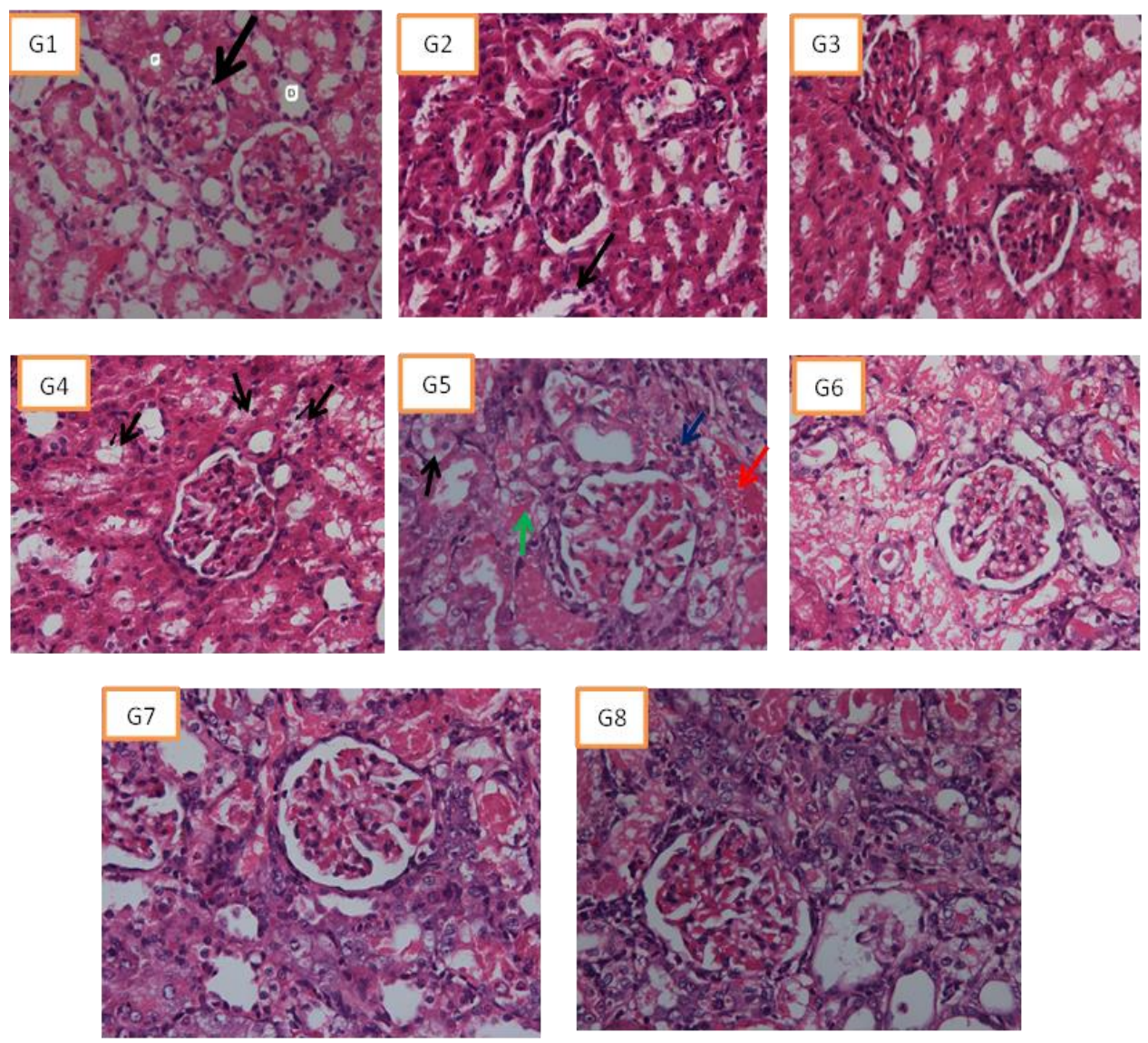

Fig(1): HISTOLOGICAL EXAMINATION

\section{DISCUSSION}

Gentamicin is widely used in clinical practice because of its efficacy against gram-negative bacterial infections, synergistic activity with $\beta$-lactam antibiotics, reduced cost, and tapered bacterial resistance. Sadeghi et al, Vol.(50); Iss.(9); No.(4); Sep. 2021

ISSN $1110-0826$

Online ISSN 2636-3178 
(2015) stated that about $30 \%$ of patients treated with gentamicin for more than a week, revealed certain symptoms of renal impairment. In addition, $10-15 \%$ of all cases of acute renal failure are attributed to gentamicin administration (Yarijani et al., 2016).

It is apparent that the toxicity of GM involves renal free radical generation, reduction in antioxidant defense mechanism; acute tubular necrosis and glomerular congestion (Martinez-Salgade et al, 2007), renal inflammatory cascades, high renal oxidative stress and associating pathological signaling mechanisms (Balakumar et al, 2010).

Grape seeds were reported to contain polyphenols and proanthocyanidin these natural products would be responsible for the potential antioxidant capacity of the grape seeds (Ozkan et al. 2012). Polyphenols and flavonoids compounds in GSE would offer sources of $\mathrm{H}$ atom donors to quench free radicals and, in turn, improve the reactive oxygen species ROS scavenging capability (Mohammed and Safwat 2019). Moreover, the powerful antioxidant activity of GSE could protect the kidney against induced nephropathy (Ozkan et al. 2012).

Guava (Psidium guajava, L.) is a tree with nutritional values and has phytochemical compounds which contains alkaloids, carotenoids, anthocyanins, vitamin-C, and triterpenes (Jayachandran et al., 2018). Previous study indicated that ethanolic extract of Psidium guajava, L. leaves has renal protective effects (Mohan et al., 2014). 
The aim of this study was to investigate the renoprotective effects of grape seeds and / or guava seeds extracts against renal damage and oxidative stress induced by GM in rats through assessment of kidney biochemical and histological parameters.

Previous evidence suggests a role of reactive oxygen metabolites in gentamicin GM toxicity (Fouad and Mahgoub 2004 and Parkakpinar et al, 2006). Gentamicin was found to enhance the generation of superoxide anions and hydroxyl radicals from renal cortical mitochondria. These oxygen free radicals play an important role in pathogenesis of nephrotoxicity by gentamicin (Fouad \& Mahgoub 2004). In the present study, gentamicin significantly increased serum creatinine and urea. Furtherly, gentamicin caused significant increase in kidney content of MDA, while the level of GSH in both blood and kidney and the activity of erythrocyte $\mathrm{Cu}, \mathrm{Zn}-\mathrm{SOD}$ were significantly decreased. Similar degrees of GM toxicity have been reported by other investigators (khan et al., 2009; Salem et al., 2010 and Salem and Salem, 2011)

The toxic renal effects of GM may be due to the interaction between molecular and subcellular components (lysosomes and mitochondria), where GM binds to the anionic phospholipids of cell membranes and gains access to the cell interior before binding to the subcellular organelles or being taken up by lysosomes. Accumulation of GM within the renal cortex is intimately related to the pathogenesis of renal failure (Erdem et al., 2000). 
Journal of Environmental Sciences (JES)

Faculty of Graduate Studies and Environmental Research, Ain Shams University

Abd Elwahab, Shaimaa A., et al.

Salem and Salem, (2011) found that the toxic renal effects of GM are manifested in significant elevation in MDA and superoxide anion production and significant reduction in GSH level and SOD, GSH-Px, and CAT activities. It is believed that reduced activity of one or more antioxidant systems because of the direct toxic effect of GM causes an increase of lipid peroxidation and oxidative stress and consequently renal toxicity (Martines -Salgade et al, 2007 and Balakumar et al, 2010).

GSE was mentioned previously to have a protective effect against gentamicin induced acute kidney injury (Safa et al, 2010). These results are matched with our finding. Moreover, it was discussed previously in many studies that GSE possess anti-apoptotic and anti-proliferation effects in renal tissue due to its antioxidant activity (Al-Rasheed et al. 2018; Elbandrawy et al. 2018). GSE may be due to its antioxidant effect, which appears to decrease the inflammatory processes which might partly explain the mechanism(s) for the amelioration of other chronic inflammatory conditions such as cancer and diabetes (Albrahim and Robert 2020). GSE displayed potential biological activities for the treatment of many diseases such as Alzheimer's disease (Fouad and Rizk 2019).

The renoprotective effects of GSE intake may be due to its multiple effects on lipid peroxidation, inflammatory mediators such as MCP-1, and cytokines such as Tumor necrosis factor alpha (TNF- $\alpha$ ) and interleukin $1 \beta$ ( IL-1 $\beta$ ), enhanced nitric oxide ( NO) release and cyclic guanosine monophosphate (cGMP) and improved lipid profile (Salem and Salem, 348 
Journal of Environmental Sciences (JES)

Faculty of Graduate Studies and Environmental Research, Ain Shams University

Abd Elwahab, Shaimaa A., et al.

2011). The authors suggested that the intake of GSE may be a feasible therapeutic strategy for prevention and treatment of patients with GM induced renal impairment.

Guava seeds are the waste of fruit industry and aren't yet used for beneficial purpose. Guava seeds are particularly rich in minerals and functional compounds like vitamin $\mathrm{C}$, crude fiber, carotenoids, and phenolic compounds (Usman et al., 2013).

Abd El - Sattar et al., (2020) found that the Total Phenolic Content (TPC) and Radical Scavenging Activity (RSA) of yoghurt prepared with guava seeds powder was increased as guava seeds powder \% increase in yoghourt product. The authors concluded that guava seeds powder could be used as natural additives to improve physicochemical, rheological and sensory properties of low fat youghurt.

In the present study providing both GM with GSE and / or guava seeds extract significantly lowered the elevated renal MDA, while it markedly raised the attenuated level of reduced GSH in both blood and kidney and the activity of erythrocytes $\mathrm{Cu}, \mathrm{Zn}, \mathrm{SOD}$. Elevating GSH in renal tissue is essential for the regulation of cell functions, maintaining cell integrity, cell protection against variety of toxins such as free radicals and their accompanied oxidative injury due to its reducing properties, and participation in the cell metabolism (Saad et al., 2009). Many studies have reported that the monomers catechin, epicatechin (monomeric flavonols), 
Journal of Environmental Sciences (JES)

Faculty of Graduate Studies and Environmental Research, Ain Shams University

Abd Elwahab, Shaimaa A., et al.

and procyanidins are the major phenolic compounds in GSE that show antioxidant activity (Singh and Agarwat, 2006 and Oszmianaki et al., 2007).

\section{CONCLUSIONS}

Our preliminary observation suggests some protective effect, by Grape Seeds Extract (GSE) on gentamicin-induced nephrotoxicity. However, there was a trend in lower levels of rise in serum creatinine and urea after treatment with grape, guava seeds extract and mixture of both.

Oral administrations of grape and guava seeds extract reduce the amount of cellular damages and oxidative stress, and as a result, it improves the function of kidneys in acute kidney injury induced by reperfusion injury in rats.

\section{REFRENCES}

El-Sattar, A., Ramadan, M. F., El-Wahed, and A.: Production of Probiotic Low-Fat Yoghurt Supplemented with Guava Seeds Powder. Journal of Food Dairy Sciences.11, 91-96, (2020).

Elbandrawy, M. M.; Taha, A. M.; Tousson, E. M.; Hassan, N. S. (2018): Different stages of hyperthyroidism: Alterations in proliferation, apoptosis, and histology of female rat ovary. Research Journal of Pharmaceutical Biological Chemical Science, 9: 1458-1471.

Albrahim,T. and Robert, A. (2020): Renal protective effects of grape seed extract treatment against Eltroxin-induced hyperthyroidism, kidney damage, and oxidative stress in male mice. Environmental Science Pollution Res, 27(15):17963-17971. 
Ali, B. H.; Al Za'abi, M.; Blunden, G. and Nemmar, A. (2011): Experimental gentamicin nephrotoxicity and agents that modify it: a mini-review of recent research, Basic clinical pharmacology toxicology. 109: 225-232.

Al-Rasheed, N. M., El-Masry, T. A., Tousson, E., Hassan, H. M., and AlGhadeer, A (2018): Hepatic protective effect of grape seed proanthocyanidin extract against Gleevec-induced apoptosis, liver Injury and Ki67 alterations in rats, Brazilian Journal of Pharmaceutical Sciences, 54.

Balakumar, P., Rohilla, A., and Thangathirupathi,A(2010): Gentamicininduced nephrotoxicity: do we have a promising therapeutic approach to blunt it, Pharmacological research. 62, 179-186.

Bao, L.; Zhang, Z.; Dai, X.; Ding, Y.; Jiang, Y.; Li, Y. and Li, Y. (2015): Effects of grape seed proanthocyanidin extract on renal injury in type 2 diabetic rats. Molecular medicine reports.11:645-652.

Beutler, E.; Duron, O. and Kelly, B. M. (1963): Improved method for the determination of blood glutathione. J. Lab. Clin. Med. 61: 882888 .

Charradi, K.; Elkahoui, S.; Karkouch, I.; Limam, F.; Hamdaoui, G.; Hassine, F. B.; El May, M. V.; El May, A. and Aouani, E. (2013): Grape seed and skin extract alleviates high-fat dietinduced renal lipotoxicity and prevents copper depletion in rat. Applied Physiology, Nutrition, Metabolism. 38: 259-267.

Dhanarajan, R.; Abraham, P. and Isaac, B. (2006): Protective effect of ebselen, a selenoorganic drug, against gentamicin-induced renal damage in rats, Basic clinical pharmacology toxicology. 99: 267-272.

Edeogu, C. O.; Kalu, M. E.; Famurewa, A. C.; Asogwa, N. T.; Onyeji, G. N. and Ikpemo, K. O.(2020): Nephroprotective Effect of Moringa Oleifera Seed Oil on Gentamicin-Induced Nephrotoxicity in Rats: Biochemical Evaluation of Antioxidant, AntiVol.(50); Iss.(9); No.(4); Sep. 2021 
inflammatory, and Antiapoptotic Pathways. Journal of the American College of Nutrition 39: 307-315.

Enginar, H.; Cemek, M.; Karaca, T. and Unak, P. (2007): Effect of grape seed extract on lipid peroxidation, antioxidant activity and peripheral blood lymphocytes in rats exposed to x-radiation.International Journal Devoted to Pharmacological. 21: 1029-1035.

Erdem, A.; Gündogan, N. Ü.; Usubütün, A.; Kılınç, K.; Erdem, Ş. R.; Kara, A., and Bozkurt, A.(2000): The protective effect of taurine against gentamicin-induced acute tubular necrosis in rats. Nephrology Dialysis Transplantation. 15: 1175-1182.

Fouad, A., and Mahgoub, S.: Protective Effects of Losartan, Garlic and Melatonin against Gentamicin-Induced Nephrotoxicity in Albino Rat. Journal of Pharmaceutical Sciences. 18, 97-100, (2004).

Fouad, G. I., and Rizk, M. Z. (2019): Possible neuromodulating role of different grape (Vitis vinifera L.) derived polyphenols against Alzheimer's dementia: treatment and mechanisms. Bulletin of the National Research Centre.43, 1-13.

Gupta, M.; Dey, S.; Marbaniang, D.; Pal, P.; Ray, S. and Mazumder, B.: Grape seed extract: having a potential health benefits, Journal of Food Science and Technology.57: 1205-1215, (2020).

Hajihashemi, S.; Jafarian, T.; Ahmadi, M.; Rahbari, A. and Ghanbari, F. (2018): Ameliorative effects of zataria multiflora hydroalcoholic extract on gentamicin induced nephrotoxicity in rats. Drug research. 68: 387-394.

IBM corp. released 2012.IBM SPSS Statistics for Windows, Version 2012. Armonk, NY: IBM corp.

Jayachandran, M.; Vinayagam, R.; Ambati, R. R.; Xu, B. and Chung, S. S. M. (2018): Guava leaf extract diminishes hyperglycemia and 
oxidative stress, prevents $\beta$-cell death, inhibits inflammation, and regulates NF-kB signaling pathway in STZ induced diabetic rats. BioMed research international, 2018.

Joseph, B. and Priya, M. (2011): Review on nutritional, medicinal and pharmacological properties of guava (Psidium guajava Linn). International Journal of pharma bio sciences. 2: 53-69.

Kenneth, E.; Paul, T.; Istifanus, N.; Uba, U.; Rejoice, A.; Victor, O. and Mohammed, S. (2017): Phytochemical analysis and antibacterial activity of Psidium guajava L. leaf extracts, Biological Pharmaceutical Sciences. 1.

Khan, S. A.; Priyamvada, S.; Farooq, N.; Khan, S.; Khan, M. W. and Yusufi, A. N. (2009): Protective effect of green tea extract on gentamicin-induced nephrotoxicity and oxidative damage in rat kidney, Pharmacological Research, 59, 254-262.

Laily, N.; Kusumaningtyas, R. W.; Sukarti, I. and Rini, M. (2015): The potency of guava Psidium guajava (L.) leaves as a Functional immunostimulatory ingredient. Procedia chemistry, 14: 301307.

Lin, C.Y. and Yin, M.C. (2012): Renal protective effects of extracts from guava fruit (Psidium guajava L.) in diabetic mice. Plant foods for human nutrition, 67: 303-08.

Lopez-Novoa, J.M.; Quiros, Y.; Vicente, L.; Morales, A. I., and LopezHernandez, F. J. (2011): New insights into the mechanism of aminoglycoside nephrotoxicity: an integrative point of view. J. Kidney international ,79: 33-45.

Mahi-Birjand,M.; Yaghoubi, S.;Abdollahpour-Alitappeh, M.; Keshtkaran, Z.; Bagheri, N.; Pirouzi, A.; Khatami, M.; Sineh Sepehr, K.; Peymani, P. and Karimzadeh, I. (2020): Protective effects of pharmacological agents against aminoglycoside-induced nephrotoxicity: A systematic review, Expert Opinion on Drug Safety 19, 167-186. 
Martinez-Salgado,C.; López-Hernández,F.J. and López-Novoa, (2007): Glomerular nephrotoxicity of aminoglycosides, Toxicology applied pharmacology, 223, 86-98.

Mohammed, E. T. and Safwat, G. M. (2019): Grape Seed Proanthocyanidin Extract Mitigates Titanium Dioxide Nanoparticle (TiO 2-NPs)Induced Hepatotoxicity Through TLR-4/NF- $\kappa B$ Signaling Pathway, Biological trace element research, 1-11.

Mohan, M.; Shashank, B. and Priya, A. V. (2014): Protective effect of Psidium guajava L. leaves ethanolic extract on doxorubicininduced nephrotoxicity in rats.

Muruganandan, S.; Srinivasan, K.; Tandan, S.; Lal, J.; Chandra, S. and Raviprakash, V. (2001): Anti-inflammatory and analgesic activities of some medicinal plants, Anti-inflammatory analgesic activities of some medicinal plants. 22: 56-58.

Oszmianski, J.; Wojdylo, A.; Lamer-Zarawska, E. and Swiader, K. (2007): Antioxidant tannins from Rosaceae plant roots, Food chemistry; 100: $579-583$.

Ozkan, G.; Ulusoy, S., Orem, A.; Ersoz, S.; Alkanat, M.; Yucesan, F. B. and Kaynar, K. (2012): Protective effect of the grape seed proanthocyanidin extract in a rat model of contrast-induced nephropathy, Kidney Blood Pressure Research. 35: 445-453.

Parlakpinar, H.; Tasdemir, S.; Polat, A.; Bay-Karabulut, A.; Vardi, N.; Ucar, M. and Acet, A. (2006): Protective role of caffeic acid phenethyl ester (CAPE) on gentamicin-induced acute renal toxicity in rats.Toxicology 207: 169-177.

Saad, A. A.; Youssef, M. I. and El-Shennawy, L. K. (2009): Cisplatin induced damage in kidney genomic DNA and nephrotoxicity in male rats: the protective effect of grape seed proanthocyanidin extract, Food Chemical Toxicology, 47: 1499-1506. 
Sadeghi, F.; Nematbakhsh, M.; Noori-Diziche, A.; Eshraghi-Jazi, F.; Talebi, A.; Nasri, H.; Mansouri, A.; Dehghani, A.; Saberi, S. and Shirdavani, S.(2015): Protective effect of pomegranate flower extract against gentamicin-induced renal toxicity in male rats.Journal of renal injury prevention. 4: 45.

Safa, J.; Argani, H.; Bastani, B.; Nezami, N.; RAHIMI, A. B.; GHORBANI, H. A.; Kalagheichi, H.; Amirfirouzi, A. and Mesgari, M., J. (2010): Protective effect of grape seed extract on gentamicininduced acute kidney injury. SOLAEYMANIRAD.

Salem, E. A., Salem, N. A.; Kamel, M.; Maarouf, A. M.; Bissada, N. K. and Hellstrom, W. (2010): Amelioration of gentamicin nephrotoxicity by green tea extract in uninephrectomized rats as a model of progressive renal failure, Renal Failure. 32: 12101215 .

Salem, N. A. and Salem, E. A. (2011): Renoprotective effect of grape seed extract against oxidative stress induced by gentamicin and hypercholesterolemia in rats. Renal Failure. 33: 824-832.

Shabbir, H.; Kausar, T.; Noreen, S.; Hussain, A.; Huang, Q.; Gani, A.; Su, S. and Nawaz, A (2020): In Vivo Screening and Antidiabetic Potential of Polyphenol Extracts from Guava Pulp, Seeds and Leaves Animal, 10: 1714.

Shi, J.; Yu, J.; Pohorly, J. E. and Kakuda, Y.: Polyphenolics in grape seeds-biochemistry and functionality, Journal of medicinal food. 6: 291-299, (2003).

Singh, R.P. and Agarwal, R. (2006): Mechanisms of action of novel agents for prostate cancer chemoprevention Endocr Relat Cancer; 13:751-778.

Sulain, M. D.; Zazali, K. E. and Ahmad, N. J. (2012): Screening on antiproliferative activity of Psidium guajava leaves extract towards selected cancer cell lines. US China Med. Sci. 9: 30-37. 
Tang, Q. ; Peng ,Z. ; Haifeng ,J.; Jun ,F.; Jintao ,Y. ; Lanqin, S. and X. (2012): Grape seed proanthocyanidins ameliorate contact hypersensitivity induced by 2, 4 dinitrofluorobenzene (DNFB) and inhibit $\mathrm{T}$ cell proliferation in vitro. J. Toxicology letters Wei. , 210: 1-8.

Turki, K.; Charradi, K.; Boukhalfa, H.; Belhaj, M.; Limam, F. and Aouani, E.: Grape seed powder improves renal failure of chronic kidney disease patients, EXCLI journal, 15: 424, (2016)

Uchiyama, M. and Mihara, M. (1978): Determination of malondialdehyde precursor in tissues by thiobarbituric acid test. Anal biochem. 86: 271-278.

Usman, M.; Samad, W. A.; Fatima, B. and Shah, M. H.: Pollen parent enhances fruit size and quality in intervarietal crosses in guava (Psidium guajava), International Journal of Agriculture Biology. 15, (2013).

Winterbourne, C. C.; Howkins, R. E.; Brain, M. and Carrell, R. W. (1975): The estimation of red cell SOD activity. J. Lab. Clin. Med. 85: 337-341

Yarijani, Z. M.; Najafi, H. and Madani, S. H.: Protective effect of crocin on gentamicin-induced nephrotoxicity in rats, Iranian Journal of Basic Medical Sciences, 19: 337, (2016).

Zhou, D.y.; Qiang ,D.u. ; Ruo-ran ,L.; Mao „H.; Qian, Z. and Guo,z. (2011): Grape seed proanthocyanidin extract attenuates airway inflammation and hyper responsiveness in a murine model of asthma by down regulating inducible nitric oxide synthase, Planta medica Wei. ; 77. 


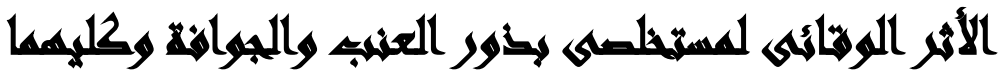

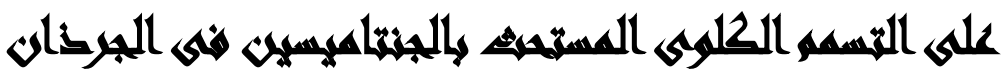

شيماء أحمد عبد الوهاب(')- مها محمود محمد (r)"- عواطف محمد عبد المقصود(r)(')

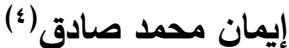

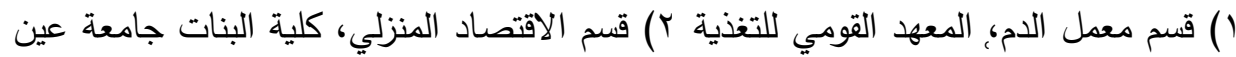

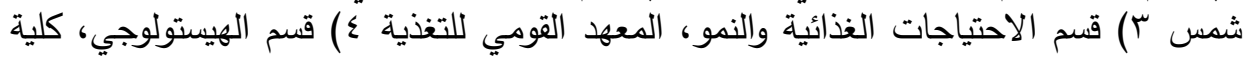
الطب، جامعة القاهرة

\section{المستصلص:}

أجريت هذه الدراسة لمعرفة التأثيرات الوقائية للكلية لمستخلصات بذور العنب و / أو بذان بذور

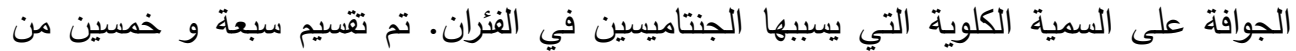

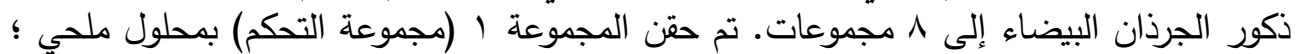

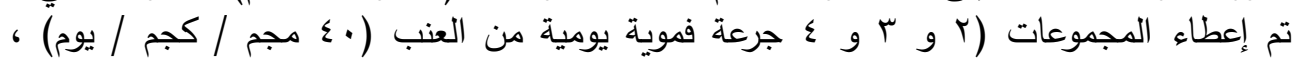

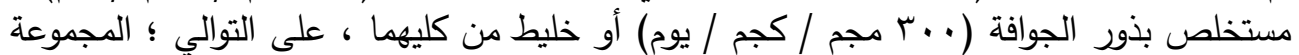

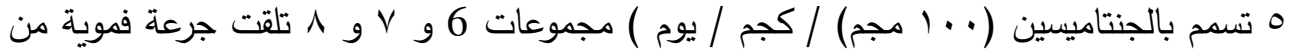

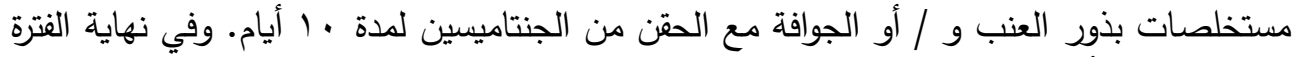

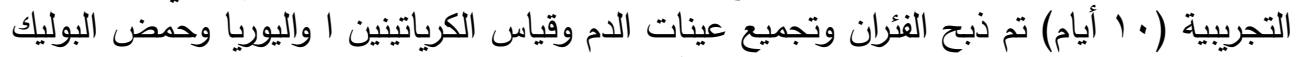

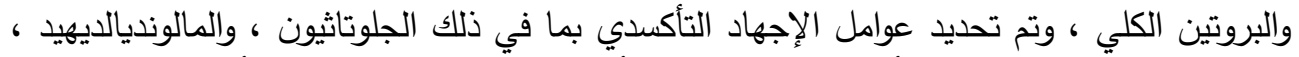

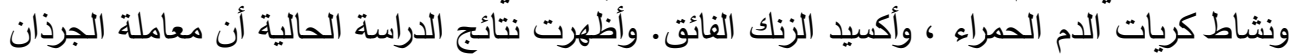

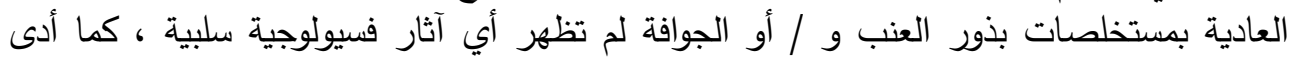

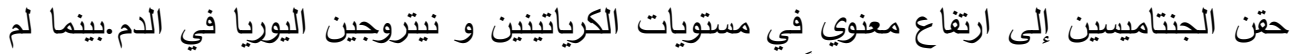

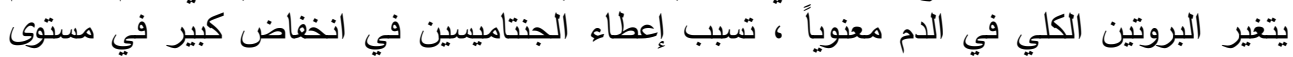

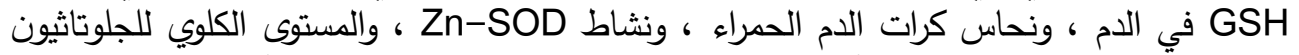

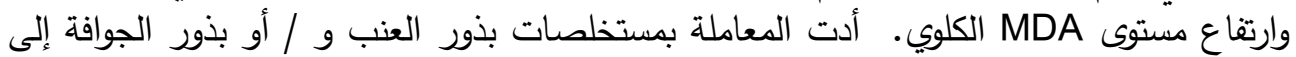
تأثيرات وقائية وتخفيف هذه التغيرات الكيميائية الحيوية. في الختام ، اقترحت هذه الدئة الدراسة أن العلاج

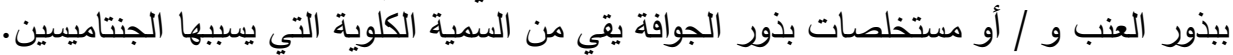

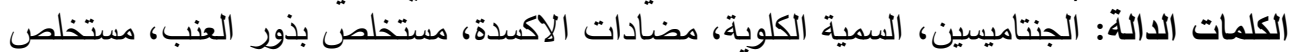

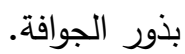

